\title{
Erratum: Where to float?
}

Nuala Moran

Nat. Biotechnol.26, 1063-1066 (2008); published online 18 August 2008, doi:10.1038/bioe.2008.8; corrected after print 5 December 2008

In the version of this article initially published, the amount of money raised in Amsterdam Molecular Therapeutics' initial public offering, recorded in Table 2 as $€ 25$ million, was incorrect. The correct amount is $€ 56$ million. The error has been corrected in the PDF version of the article and in the HTML version on the Bioentrepreneur portal.

\section{Erratum: Reply to Field-evolved resistance to Bt toxins}

Bruce E Tabashnik, Aaron J Gassman, David W Crowder \& Yves Carrière

Nat. Biotechnol. 26, 1074-1076 (2008); published online October 2008; corrected after print 5 December 2008

In the version of this article initially published, the second author's name was misspelled. The correct spelling is Gassmann. The error has been corrected in the HTML and PDF versions of the article.

\section{Erratum: Actemra poised to launch IL-6 inhibitors}

Lisa Melton with additional reporting by Amy Coombs

Nat. Biotechnol. 26, 957-959 (2008); published online 7 November 2008; corrected after print 5 December 2008

In the version of this article initially published, on p. 958, right-hand column, line 2, it was incorrectly stated that Rituxan is used for treating multiple sclerosis: "Rituxan (rituximab), a B cell-depleting biologic for treating rheumatoid arthritis and multiple sclerosis, has shifted the focus towards B cells." The sentence should have read, "Rituxan (rituximab), a B cell-depleting biologic for treating rheumatoid arthritis and non-Hodgkin's lymphoma, has shifted the focus towards B cells." The error has been corrected in the HTML and PDF versions of the article. 